\title{
Floral structure and genetical differences of sandalwood variants in Gunung Sewu (Java, Indonesia), and its effects on breeding systems and reproductive ability
}

\author{
YENI W.N. RATNANINGRUM ${ }^{1, \boldsymbol{v}}$, AFFAN KURNIAWAN ${ }^{2}$ \\ ${ }^{1}$ Tree Improvement Laboratory, Faculty of Forestry, Universitas Gadjah Mada. Bulaksumur, Sleman 55281, Yogyakarta, Indonesia. \\ Tel.: +62-274-550543, ’email: yeni.wnr@ugm.ac.id; yeniratnaningrum@gmail.com \\ ${ }^{2}$ Department of Silviculture, Faculty of Forestry, Universitas Gadjah Mada. Bulaksumur, Sleman 55281, Yogyakarta, Indonesia
}

Manuscript received: 18 March 2018. Revision accepted: 18 January 2019.

\begin{abstract}
Ratnaningrum YWN, Kurniawan A. 2019. Floral structure and genetical differences of sandalwood variants in Gunung Sewu (Java, Indonesia), and its effects on breeding systems and reproductive ability. Biodiversitas 20: 393-404. Our preliminary studies reported that the failure on rehabilitation program of sandalwood, an endangered endemic species in Indonesia, was caused by low viability and survival due to reproductive failure. New sandalwood landraces in Gunung Sewu Geopark, Java island consist of three variants (YBF, refers to "yellow big flower"; RBF, "red big flower"; and RSF, "red small flower") differed by floral structures. This study was made on three sandalwood variants grew in four landraces representing landscape zones in Gunung Sewu, from April to September 2017 flowering season. This advanced study was aimed to estimate the differences in floral structures and genetic diversity among variants, and their effects on breeding systems and reproductive ability. Floral organ measurements were made on each variant. Isoenzyme analysis was conducted to estimate the genetic diversity of each variant and in each site. Mating systems were estimated by Index of Incompatibility (ISI) and Cruden's Out Crossing Index (OCI) methods. Reproductive ability was measured by counting Pollination Effectiveness, Reproductive Success and seed viability. Results found that six loci were polymorphic in most of sites and variants, with exception for Petir and Bejiharjo sites and YBF variant. Observed heterozygosity varied with sites but was similar among variants. Some of diversity existed among both sites and variants. The OCI value scored more than 3 for all variants, indicating an outbreeding mating system. RSF showed higher OCI value compared to both RBF and YBF. Bleberan and Nglanggeran, the outcrossed and completely self-incompatible populations (ISI $=0$ ), failed to produce selfed seeds. In such highly outcrossing, self-incompatible populations, the highest seed set was gained from intraspecific-crossed pollination. Contrastly, the inbreeding and self-compatible populations (ISI $=3$ to $\infty$ ), Petir and Bejiharjo, tended to alter its matting system to be more inbreeding. Reproductive ability differed by sites but was similar among variants.
\end{abstract}

Keywords: Breeding systems, genetic diversity, Gunung Sewu, reproductive ability, sandalwood floral variants

\section{INTRODUCTION}

Islands in the eastern part of Indonesia are considered to be the origin of recently existed Santalum album L. -hereinafter referred to sandalwood - worldwide (Harbaugh and Baldwin 2007; Rao et al. 2007; da Silva et al. 2016). Sandalwood is among the most economic-important species since its heartwood, containing $20 \%$ to $50 \% \alpha$ santalol and $10 \%$ to $36 \% \beta$-santalol, is widely used for wood carving, religious and medicinal purposes. The price of sandals heartwood in India is continuously increased from 20 thousand to 200 thousand Rupee within the last ten years from 1997 to 2007 (UNEP 2007). In Indonesia, the price ranged from 9,000 to 18,000 Rupiahs/kg in 1990's (Bano 2001), but extremely increased within a range of 600,000 to 1 million Rupiahs $/ \mathrm{kg}$ in 2017 (https://www.harga.top; accessed December 18, 2017). In international market, it costs $\$ 9,400 /$ tonne in 1990 and raised up to $\$ 150,000 /$ tonne in 2014 (da Silva et al. 2016). Sandalwood oil, having a strong-specific fragrance and widely known as "liquid gold", has been used as a prime source of cosmetics, perfumes and aromatherapy, and is considered to have anti-melanoma compounds (Rao et al.
2007; da Silva et al. 2016). Sandalwood oil costs US\$ $1,250 / \mathrm{kg}$ in 2006 (Harbaugh and Baldwin 2007), and raised to more than US\$5,000/kg in 2015 (da Silva et al. 2016). In 1994, IUCN Red List has first listed sandalwood as Vulnerable due to the habitat degradation and loss (IUCN 1994). In 2012, re-inventory of sandalwood in Timor confirmed more than $100 \%$ reduction on population size within less than three generations (equal to ten years) (Kementerian Kehutanan RI 2007) and therefore, the extinction status in IUCN Red List supposed to be reevaluated. The Vulnerable level might have raised to Critically Endangered or even Extinct in the Wild (IUCN 2009).

In 2015, Indonesian government reported the failure on rehabilitation program of sandalwood due to very low seed viability and survival. Our previous studies revealed that reproductive failure is the most responsible factor for this rapid reduction of viability and survival (Indrioko and Ratnaningrum 2015; Ratnaningrum et al 2015, 2017a). Those studies reported that the low genetic base, high clonality, and fragmentation were among the main factors causing reproductive failure, since it resulted in heterozygosity reduction and inbreeding. Similar case has 
also widely reported in Santalum lanceolatum in Australia (Warburton et al. 2000), S. spicatum in Western Australia (Byrne et al. 2003), S. insulare in Pacific islands (Lhuillier et al. 2006), S. album in Peninsular India (Rao et al. 2007) and Southern India (Dani et al. 2011), and $S$. austrocaledonicum in New Caledonia (Bottin et al. 2007).

Reproductive failure might exist as a result of genetic mechanisms, such as self-incompatibility, which might occur in mating between relatives (Rao et al. 2007; Salisbury et al. 2017; Yang et al. 2017). Reproductive failure might also occurred as a result of mating barriers due to the differences on floral structures and biology among individuals within population, that in turn lead to a mating incompatibility (Rughkla et al. 2006; Barrett 2011; Tamla et al. 2012; Gan et al. 2013; Salisbury et al. 2017; Yang et al. 2017). In such cases, pollination barrier occurred due to the differences on the length of stylus and/or filament, structures of corolla, stigma-anthers position (Rughkla et al. 2006; Fernandez et al. 2009; Tamla et al. 2012), pistil dysfunction, male sterility (SindhuVereendra and Anantha-Padmanabha 1996; Warburton et al. 2000) and/or flowering asynchrony (Ratnaningrum et al. 2016, 2017b, 2018). Self-incompatibility due to self-mating in sandalwood has reported in Petir and Bejiharjo landraces, Gunung Sewu (Indrioko and Ratnaningrum 2015) and Western Australia (Warburton et al. 2000). Whilst, mating barriers due to different floral structures has found in S. album in Gunung Sewu (Ratnaningrum et al. 2018), S. lanceolatum and S. spicatum in Western Australia (Tamla et al. 2012).

Considering a rapid degradation of sandalwood population in its native in the eastern parts of Indonesia, the occurrence of new landraces in Gunung Sewu Geopark, a $1300 \mathrm{~km}^{2}$ mountainous limestone zones in the central part of Java island, may provide a promising source for any of rehabilitation efforts. Our preliminary studies revealed that population with wider genetic base have higher outcrossing rate, genetic diversity and reproductive ability (Ratnaningrum et al. 2015, 2017a, 2018). In contrary, the low genetic base, fragmentation and clonality may reduce genetic diversity and alter the mating system to be more inbred (Indrioko and Ratnaningrum 2015; Ratnaningrum et al. 2015, 2017a), inhibit gene flow (Ratnaningrum et al. 2017a), and increase reproductive failure (Indrioko and Ratnaningrum 2015; Ratnaningrum et al. 2017a, 2018). Landraces in Gunung Sewu consist of three variants (OBF, refers to "orange big flower"; RBF, "red big flower"; and RSF, "red small flower", respectively) differed in floral structures (Syahbudin et al. 2005; Arifriana et al. 2017), flowering (Ratnaningrum et al. 2017b) and pollination events (Fathin and Ratnaningrum 2018). These floral differences are considered to be a cause of mating barriers (Ratnaningrum et al. 2017a, 2017b). The best result of reproductive outputs was gained from cross-intraspecific mating within the same variants, and contrarily, variants with different floral structure failed to intermate (Ratnaningrum et al. 2017b).

Our preliminary estimation on the breeding system of sandalwood has conducted both by isozyme-based analysis to count the value of $t$ (outcrossing rate) (Ratnaningrum et al. 2015), and by hand-pollination experiments to count the value of $s$ (selfing rate), $t$ and inbreeding depression (Indrioko and Ratnaningrum, unpublished data). However, it was in a small scale level with the limited number of samples. Moreover, in our knowledge, none of floral character-based studies have ever been conducted to estimate the breeding system of sandalwood. Several methods which correlate floral characters with the plant preference to outcross or inbreed, are the Index of Self Incompatibility (ISI) and Cruden's Outcrossing Index (OCI) methods. The breeding system estimation based on ISI and OCI values has reported in Schima superba (Yang et al. 2017) and Tetracentron chinense (Gan et al. 2013) in the tropical Southern China region, and several Brassicaceae in Australia (Salisbury et al. 2017).

This study, conducted during April to September 2017 flowering season, is the next step to determine the cause of reproductive failure which is related to the differences on floral structures and genetic diversity, since these differences may cause different genetical mechanisms and breeding systems. This study aimed to answer this hypothesis (i) the floral structures and heterozygosity differed by variants; (ii) the difference on the floral structures and heterozygosity cause the differences on breeding systems; and (iii) the difference on floral structures, heterozygosity and breeding systems affect the reproductive ability. Floral organ measurements were made on three sandalwood variants (RBF, RSF, and YBF) grew in four landraces representing landscape zones in Gunung Sewu. Isoenzyme analysis was conducted to estimate the genetic diversity of each variant and in each site. Mating systems were estimated by Index of Incompatibility (ISI) and Cruden's Out Crossing Index (OCI) methods. Reproductive ability was measured by counting the Pollination Effectiveness, Reproductive Success and seed viability.

\section{MATERIALS AND METHODS}

\section{Study sites}

Gunung Sewu consisted of nine sandalwood landraces, however, this research was only conducted at four landraces which represented distinctively different population structures: one of landrace (the basin of Bleberan) in the Middle Zone, two (the highland of Nglanggeran and the lowland cave of Bejiharjo) in the Northern Zone, and one (the karst area Petir) in the Southern Zone, respectively. Each of landrace is separated by 25 to $40 \mathrm{~km}$. These landraces are located at different altitude, experienced different climatic regimes and having clear ecological differences (Table 1).

\section{Study species}

Sandalwood observed in this study is a yearly flowering perennial sub-shrub of semi-arid and tropical regions (Ratnaningrum et al. 2016). Preliminary studies in this species found the dichogamy type, highly outcrossing rate and self-incompatibility (Ratnaningrum and Indrioko 2015; Ratnaningrum et al. 2016, 2017b, 2018), even in some 
cases, partially self-compatibility has also been reported (Ratnaningrum et al. 2015, 2017a). In the study sites, sandalwood has preference to propagate vegetatively by producing root suckers, sprouting emerged from the horizontal roots. In several sites, clonality event existed when most of off-springs in population were derived from a genetically identic individual (Indrioko and Ratnaningrum 2015; Ratnaningrum et al. 2015). Sandalwood also has very low reproductive success (ranged from $0.03 \%$ in natural population to less than $20 \%$ in ex-situ plantation; Ratnaningrum et al. 2016); however cross-pollination tends to enhance seed set (Ratnaningrum et al. 2015).

Sandalwood in all study sites is consisted of three variants (YBF, refers to "yellow big flower"; RBF, "red big flower"; and RSF, "red small flower", respectively) differed by floral structures (Syahbudin et al. 2005; Arifriana et al. 2017; Ratnaningrum et al. 2017b). The RSF and RBF dominated by red and dark maroon colors, while $\mathrm{YBF}$ is more yellowish to orange. The RBF and YBF possessed bigger perigonium, longer sexual organs but with shorter longevity, and similar/lower position of pistil to stamens. RSF flowers are smaller, similar/higher position of pistil, and have longer longevity. Sandalwood flowered twice a year in all of sites and variants, however, the initiation and duration are varied. YBF flowered earliest while RBF was the latest. The RSF possessed longest flowering period (Ratnaningrum et al. 2017b). Flowering and floral differences among variants were considered to be under genetic controls, while the variation among sites was affected more by environmental differences (Ratnaningrum and Indrioko 2015; Ratnaningrum et al. 2016, 2017b). More detail data on floral structures, sexual organs longevity and flowering phenology of these three variants are available at Ratnaningrum et al. (2017b).

Table 1. Population structures and the habitat characteristics of study sites (Ratnaningrum et al. 2015)

\begin{tabular}{cccc}
\hline $\begin{array}{c}\text { Landrace, } \\
\text { width, } \\
\text { altitude, } \\
\text { climatic types }\end{array}$ & $\begin{array}{c}\text { Landscape history and present } \\
\text { habitat characteristics }\end{array}$ & $\begin{array}{c}\text { Soil and rock } \\
\text { units }\end{array}$ & $\begin{array}{c}\text { Sandalwood history and present population } \\
\text { characteristics }\end{array}$ \\
\hline
\end{tabular}

Nglanggeran;

$79.3 \mathrm{ha}$;

710-750m asl

Am type

Bejiharjo; 9.6

ha;

150-180m asl;

Aw type
A part of Nglanggeran Formation, Northern Zone of Gunung Sewu.

Now existed as the mountain

landscapes, strong undulating, characterizing tropical mountain ecosystems.

A part of Sambipitu Formation, Northern Zone of Gunung Sewu. Now existed as the open dryrocky hilly landscapes with caves and ground-rivers below. Representing the dryland ecosystems.
Latosols with volcanic and sediment rocks, some with deeper solum.

The association of red mediterraneans and black grumusols with limestone rocks, mostly with the shallow solum
The association of red mediterraneans and black grumusols with limestone rocks, mostly with the deeper solum.

asl;

intermediate

between $A w$ and $A m$ type

Petir;

78 ha;

70-100m asl; Aw type
A part of Wonosari Basin Gunung Sewu. Now existed as the catchment area of the ancient subterranean Oya River at the lowland basin landscapes. Representing the tropical lowland ecosystems.

A part of Wonosari-Punung Karst Formation, Southern Zone of Gunung Sewu. Now existed as the karst hilly landscapes with open dry-rocky hills, strong undulating, characterizing the dry rockylimestone ecosystems.

Sandalwood was first documented in 1970's. Recently occurred in groups of stands across the Nglanggeran mountain regions, in association with the tropical mountain vegetation. Habitat dominated by the association of naturally regenerated mahogany, Gliricidia sp, and several Garcinia and Eugenia families.

Sandalwood is a remnant of the 1970's planted stands. Fragmented due to heavy exploitation, urban and cavetourism activities since 1990's. Now existed as a smallfragmented group of stands, dispersedly occurred in open dry-rocky hills above the caves and ground-rivers. Sandalwood grew in an association with cajuputi and acacia regenerated from commercial plantation nearby. Younger sandal trees were largely derived from root suckers. Sites dominated by dryland herbs such as grasses and Eupatorium sp.

Sandalwood was first documented in 1970's along the catchment area of the ancient subterranean Oya River, at the lowland basin of middle zone. Sandalwood dispersed widely along the riparian catchment area and nearby, in association with the tropical lowland forest vegetation which is consisted of more diverse vegetation including teak, mahogany, Gliricidia sp, Schleichera sp, cajuputi, and acacia. Population is surrounded by several ex situ conservation areas which are sharing the same river.

Latosols with limestone rocks. Solum is deeper at the basins, but very shallow at the limestone-rocky hills.
Sandalwood was first documented in 1960's in karst hilly areas, recently covering more than twenty open dry-rocky hills. Adult plants were mostly derived from root suckers; highly clonalized. In the open-undulating areas, sandalwood grew in association with dry rocky-limestone vegetation including acacia and cajuputi, but more dominated by shrubs and herbs such as grasses and Eupatorium sp. 


\section{Isozyme-based genetic diversity measurements}

Genetic diversity was estimated spatially among four landraces along geographical gradients in Gunung Sewu. At the beginning of dry season in April 2017, juvenile leaves were sampled from randomly chosen individuals. To avoid the re-sampling of same siblings, it should be ensured that the sampled trees were not sharing the same root systems. The flowering trees were of the first priority to be sampled. Samples were wrapped and frozen in ice packs before allozyme extraction and electrophoresis. Previous study gained three enzymes, shikimate dehydrogenase (E.C. 1.1.1.25.), esterase (E.C. 3.1.1.) and diaphorase (E.C. 2.6.4.3.) which observed to be polymorphic (Indrioko and Ratnaningrum 2015; Ratnaningrum et al. 2015). The interpretable zymogram phenotypes were found for six loci: shikimate dehydrogenase $S k d-1$, esterase Est-1, Est-2, and Est-3, and diaphorase Dia-1 and Dia-2. Electrophoretic were conducted with vertical polyacrylamide gel electrophoresis procedures following David-Ornstein method (Seido 1993). The leaves were homogenized in modified extraction buffer (Sigma Inc., USA) and centrifuged at 15,000 rpm for $15 \mathrm{~min}$ at $4^{\circ} \mathrm{C}$. The supernatant was loaded onto polyacrylamide vertical slab gels (Sigma Inc., USA) and electrophoresed at $4{ }^{\circ} \mathrm{C}$ at $220 \mathrm{~V}$ and $200 \mathrm{~mA}$ current for about $3 \mathrm{~h}$. After electrophoresis, the gels were stained using staining solution of each enzyme system, and the allozyme gels were genetically interpreted.

At each locus, the allele frequency and genotype were counted following Seido (1993). For each locus, the number of heterozygote genotype were counted and represented as percent observed heterozygosity $\left(\mathrm{H}_{\mathrm{o}}\right)$. The observed heterozygosity was then pooled and averaged over all loci to determine the percent observed heterozygosity for a population. The expected heterozygosity $\left(\mathrm{H}_{\mathrm{e}}\right)$ for each locus and over all loci for each population in Hardy-Weinberg equilibrium was counted following the formula: $\mathrm{H}_{\mathrm{e}}=1-\Sigma \mathrm{p}_{\mathrm{i}}{ }^{2}$, where $\mathrm{p}_{\mathrm{i}}$ refers to the $i$ 's allele frequency of a given population. Total population heterozygosity $\left(\mathrm{H}_{\mathrm{T}}\right)$ was counted following the formula: $\mathrm{H}_{\mathrm{e}}$ $=1-\Sigma \mathrm{p}_{\mathrm{it}}{ }^{2}$, where $\mathrm{p}_{\mathrm{it}}$ refers to the $i$ 's allele frequency of the populations in total. Fixation index, the deviation from expected frequencies under Hardy-Weinberg equilibrium, was measured following the formula: $F_{\text {is }}=1-\mathrm{H}_{\mathrm{o}} / \mathrm{H}_{\mathrm{e}}$. To measure genetic differentiation, genetic diversity between populations $\left(\mathrm{D}_{\mathrm{ST}}\right)$ was calculated by reducing the value of total heterozygosity $\left(\mathrm{H}_{\mathrm{T}}\right)$ to heterozygosity within population $\left(\mathrm{H}_{\mathrm{S}}\right)$. The mean proportion of total gene diversity at polymorphic loci due to differences between populations $\left(\mathrm{G}_{\mathrm{ST}}\right)$ was measured by dividing $\mathrm{D}_{\mathrm{ST}}$ to $\mathrm{H}_{\mathrm{T}}$

\section{Estimation on breeding system}

Breeding system estimation based on the value of Cruden's Outcrossing Index

Measurement was made on the length of stylus and filament at each of 30 single flowers at fully anthesis phase per variant. Total $\mathrm{N}=30$ single flowers $\mathrm{x} 3$ variants $\mathrm{x} 4$ sites $=360$ single flowers. Cruden's Outcrossing Index (Salisbury et al. 2017) was measured by totalling the score of these three characters: (i) Flower diameter: $<1 \mathrm{~mm}=0$;
$1-2 \mathrm{~mm}=1 ; 2-6 \mathrm{~mm}=2 ;>6 \mathrm{~mm}=3$; (ii) Temporal separation of maturity between male and female sexual organs: concurrently $=0$; mature at different time $=1$; (iii) Spatial separation between male and female sexual organs: pistil and stamen are not separated, located within a similar position with a possibility to inter-mate $=0$; pistil and stamen are spatially separated $=1$. Plant is classified into outcrossing taxa when the value of Cruden's Outcrossing Index is equal to more than 3 .

\section{Breeding system estimation based on hand-pollination experiments and the value of ISI (Index of Self \\ Incompatibility)}

In each of landrace, hand pollination experiments were applied by performing two types of mating: self- and crossmating (Owens et al. 2001). To support cross-pollination, filaments were emasculated at the early anthesis in the morning (06:00 to 08:00 a.m.) to remove immature anthers. Receptive stigma was pollinated by a selected pollen source (male parent) by applying the mature anther to the stigma in 3 times replication to ensure the pollen transfers. Each inflorescence was then tagged and isolated using fine fabrics. To perform self-pollination, single inflorescence was isolated using fine fabrics prior to anthesis. Total $\mathrm{N}$ for self hand-pollination was 3 variants x 3 individuals x 50 single flowers $=450$ single flowers at each of landrace. While, cross hand-pollination was applied only at intraspecific (within variant) level. Total $\mathrm{N}$ per female parent: 30 replication $\times 3$ variants of male parent $=90$ single flowers. Total $\mathrm{N}$ per site: 3 variants of female parents' x 3 replication x 90 single flowers $=810$ single flowers. Each of female parents was reciprocally crossed to the pollen of each.

Counting was then made on: (i) The ISI (Index of Self Incompatibility) value. ISI (Index of Self Incompatibility), the self-incompatible level of a given species, is calculated by dividing the output of selfing to the output of crossing (Yang et al. 2017). ISI value more than 1 is considered self-compatible; ISI between 0.2 to 1 is partially selfincompatible; ISI less than 0.2 is mostly self-incompatible, and ISI 0 is completely self-incompatible. (ii) The Reproductive Success of the three types of mating.

To measure reproductive success (Owens et al. 2001), the flowers and mature seeds were counted at each type of mating, and the value of Reproductive Success (RS) -corresponding to the ability of reproductive organs to form mature seeds-- was measured following the formula, RS = (Fruit/Flower) x (Seed/Ovule).

\section{The reproductive outputs from natural pollination of sandalwood at different landraces and variants The value of pollination effectiveness and reproductive success}

To measure reproductive outputs, the value of Pollination Effectiveness and Reproductive Success resulted from open pollination was counted. Every three flowered individuals per variant were selected at each of landrace. In total, the number of individually selected for this experiment was $N=3$ replications $x 3$ variants $x 4$ landraces $=36$ individuals. At each individual selected, ten 
inflorescences were tagged and the number of single flowers was counted. After the natural pollination and fertilization processes, the number of fertilized flower (young fruits) was counted. At the end of fruiting phase, the mature fruits were counted and picked. The value of Pollination Effectiveness (PE) -refers to the ability of reproductive organs to carry out the successful pollination and fertilization-- was measured following Owens et al. (2001), PE = the number of fertilized flower divide the number of flower. Reproductive Success (RS) was measured following the formula, RS $=$ (Fruit/Flower) $\mathrm{x}$ (Seed/Ovule). As the fruit of sandalwood is a singleseeded, in which each of fruit is derived from ovary bearing only one ovule, therefore the seed/ovule equal to 1 .

\section{Seed viability}

To determine seed viability, all mature seeds were collected from the sampled individuals. Seed extraction and scarification were conducted following Mooy et al. (2013). Seeds were soaked in the water for 24 hours, manually extracted, and air dried under room temperature. Both direct and indirect viability test was conducted following Copeland and McDonald (2001). Seeds were germinated by sowing in sterile sands media, and seed viability was measured by dividing the number of germinated seeds to the total of sowed seeds. Indirect viability test was conducted by cutting and soaking seeds in 2,3,5 Triphenyl Tetrazolium Chloride: aquadest (1:100). After four hours, the viable seeds were represented by the occurrence of red color in the seed tissues, indicated the activity of living cells.

\section{RESULTS AND DISCUSSIONS}

\section{Genetic diversity of three sandalwood variants in each of landrace}

Six loci (Est-1, Est-2, Est-3, Dia-1, Dia-2, and Skd-1) were polymorphic for all of floral variants in Bleberan and Nglanggeran landraces. Monomorphism was observed in most of all loci was found in Petir and Bejiharjo landraces, particularly for YBF variant (only Est-1 is polymorphic). YBF variant showed some polymorphism only in Bleberan and Nglanggeran; while in Petir and Bejiharjo, most of all loci were monomorphic, indicating the high homozygosity and loss of many alleles. Allele distribution was similar among sites, but was differed among floral variants. The Dia-1 loci of YBF variant was dominated by "c" allele, while those of RSF and RBF was dominated by "b" allele. In Skd-1 loci, allele "a" dominated the RBF and RSF variants, while YBF was dominated by "c" allele (Table 2).

Table 2. The allele frequencies at each locus of three sandalwood floral variants in four landraces in Gunung Sewu, Java, Indonesia

\begin{tabular}{|c|c|c|c|c|c|c|c|c|c|c|c|c|c|c|c|}
\hline \multicolumn{6}{|l|}{ Loci } & \multirow{2}{*}{\multicolumn{2}{|c|}{ Allele }} & \multicolumn{6}{|l|}{ Loci } & \multirow{2}{*}{\multicolumn{2}{|c|}{ Allele }} \\
\hline Shd-1 & Dia-2 & Dia-1 & Est-3 & Est-2 & Est-1 & & & Shd-1 & Dia-2 & Dia-1 & Est-3 & Est-2 & Est-1 & & \\
\hline & & & & & & \multicolumn{2}{|c|}{ Bleberan } & & & & & & & \multicolumn{2}{|c|}{ Nglanggeran } \\
\hline 0.680 & 0.020 & 0.080 & 0.540 & 0.760 & 0.320 & $\mathrm{a}$ & & 0.618 & 0.255 & 0.069 & 0.804 & 0.794 & 0.137 & $\mathrm{a}$ & \\
\hline 0.120 & 0.940 & 0.880 & 0.460 & 0.240 & 0.680 & b & $\mathrm{RBF}$ & 0.118 & 0.667 & 0.853 & 0.196 & 0.206 & 0.863 & $\mathrm{~b}$ & $\mathrm{RBF}$ \\
\hline 0.200 & 0.040 & 0.040 & & & & $\mathrm{c}$ & & 0.265 & 0.078 & 0.078 & & & & $\mathrm{c}$ & \\
\hline 0.483 & 0.114 & 0.218 & 0.497 & 0.365 & 0.435 & HS & & 0.535 & 0.484 & 0.262 & 0.315 & 0.327 & 0.237 & HS & \\
\hline 0.344 & 0.031 & 0.031 & 0.828 & 0.844 & 0.172 & $\mathrm{a}$ & & 0.190 & 0.095 & 0.036 & 0.857 & 0.810 & 0.095 & $\mathrm{a}$ & \\
\hline 0.063 & 0.938 & 0.313 & 0.172 & 0.156 & 0.828 & $\mathrm{~b}$ & YBF & 0.060 & 0.881 & 0.179 & 0.143 & 0.190 & 0.905 & $\mathrm{~b}$ & YBF \\
\hline 0.594 & 0.031 & 0.656 & & & & $\mathrm{c}$ & & 0.750 & 0.024 & 0.786 & & & & $\mathrm{c}$ & \\
\hline 0.525 & 0.119 & 0.471 & 0.285 & 0.264 & 0.285 & HS & & 0.398 & 0.214 & 0.349 & 0.245 & 0.308 & 0.172 & HS & \\
\hline 0.470 & 0.152 & 0.030 & 0.591 & 0.833 & 0.288 & $\mathrm{a}$ & & 0.671 & & 53 & 0.842 & 0.868 & 0.211 & $\mathrm{a}$ & \\
\hline 0.106 & 0.833 & 0.924 & 0.409 & 0.167 & 0.712 & b & $\mathrm{P}$ & 0.039 & 11 & 0.789 & 0.158 & 0.132 & 0.789 & $\mathrm{~b}$ & RSF \\
\hline 0.424 & 0.015 & 0.045 & & & & c & & 0.289 & & 0.158 & & & & $\mathrm{c}$ & \\
\hline 0.588 & 0.282 & 0.143 & 0.483 & 0.278 & 0.410 & HS & & 0.464 & 0.445 & 0.349 & 0.266 & 0.229 & 0.332 & HS & \\
\hline & & & & & & Pet & & & & & & & & De & \\
\hline 0.742 & 0.106 & 0.000 & 1.000 & 1.000 & 0.015 & $\mathrm{a}$ & & 0.640 & 0.000 & 0.000 & 0.990 & 0.980 & 0.020 & $\mathrm{a}$ & \\
\hline 0.000 & 0.879 & 1.000 & 0.000 & 0.000 & 0.985 & $\mathrm{~b}$ & $\mathrm{RBF}$ & 0.000 & 0.960 & 0.950 & 0.010 & 0.020 & 0.980 & $\mathrm{~b}$ & RBF \\
\hline 0.258 & 0.015 & 0.000 & & & & c & & 0.360 & 0.040 & 0.050 & & & & $\mathrm{c}$ & \\
\hline 0.382 & 0.216 & 0.000 & 0.000 & 0.000 & 0.030 & HS & & 0.461 & 0.077 & 0.095 & 0.020 & 0.039 & 0.039 & HS & \\
\hline 0.028 & 0.000 & 0.000 & 1.000 & 1.000 & 0.000 & $\mathrm{a}$ & & 0.000 & 0.000 & 0.000 & 1.000 & 1.000 & 0.000 & $\mathrm{a}$ & \\
\hline 0.194 & 0.903 & 0.000 & 0.000 & 0.000 & 1.000 & $\mathrm{~b}$ & YBF & 0.000 & 1.000 & 0.154 & 0.000 & 0.000 & 1.000 & $\mathrm{~b}$ & YBF \\
\hline 0.778 & 0.097 & 1.000 & & & & $\mathrm{c}$ & & 1.000 & 0.000 & 0.846 & & & & $\mathrm{c}$ & \\
\hline 0.356 & 0.176 & 0.000 & 0.000 & 0.000 & 0.000 & HS & & 0.000 & 0.000 & 0.260 & 0.000 & 0.000 & 0.000 & HS & \\
\hline 0.825 & 0.000 & 0.100 & 1.000 & 0.988 & 0.013 & $\mathrm{a}$ & & 0.786 & 0.000 & 0.014 & 1.000 & 1.000 & 0.000 & $\mathrm{a}$ & \\
\hline 0.000 & 0.938 & 0.900 & 0.000 & 0.013 & 0.988 & $\mathrm{~b}$ & RSF & 0.014 & 0.971 & 0.943 & 0.000 & 0.000 & 1.000 & $\mathrm{~b}$ & RSF \\
\hline 0.175 & 0.063 & 0.000 & & & & c & & 0.200 & 0.029 & 0.043 & & & & $\mathrm{c}$ & \\
\hline 0.289 & 0.117 & 0.180 & 0.000 & 0.025 & 0.025 & HS & & 0.342 & 0.056 & 0.109 & 0.000 & 0.000 & 0.000 & HS & \\
\hline
\end{tabular}

Note: Null number in grey background represents the missing alleles 
Table 3. The genetic parameters measurements of three sandalwood floral variants in four landraces in Gunung Sewu, Java, Indonesia

\begin{tabular}{|c|c|c|c|c|c|c|c|c|c|c|}
\hline \multirow{2}{*}{ Landraces and floral variants } & \multicolumn{3}{|c|}{ Population structures } & \multicolumn{7}{|c|}{ Genetic parameters } \\
\hline & Flowered indiv. & Sampled indiv. & $\begin{array}{c}\text { Clonality } \\
(\%) *\end{array}$ & $\mathbf{H e}_{\mathbf{e}}$ & $\mathbf{H}_{\mathbf{o}}$ & $F_{\text {is }}$ & Hs & $\mathbf{H}_{\mathbf{T}}$ & DST & GST \\
\hline \multicolumn{11}{|l|}{ Landraces and variants } \\
\hline \multicolumn{11}{|l|}{ Nglanggeran } \\
\hline - Red-big flower & 87 & 51 & 0 & 0.360 & 0.317 & 0.119 & & & & \\
\hline - Yellow-big flower & 66 & 42 & 0 & 0.281 & 0.230 & 0.181 & & & & \\
\hline - Red-small flower & 58 & 38 & 0 & 0.347 & 0.355 & -0.022 & & & & \\
\hline Average & 70 & 44 & 0 & 0.330 & 0.301 & 0.093 & & & & \\
\hline \multicolumn{11}{|l|}{ Bejiharjo } \\
\hline - Red-big flower & 112 & 50 & 75.66 & 0.122 & 0.087 & 0.288 & & & & \\
\hline - Yellow-big flower & 28 & 13 & 98.00 & 0.043 & 0.013 & 0.705 & & & & \\
\hline - Red-small flower & 78 & 35 & 77.30 & 0.084 & 0.071 & 0.155 & & & & \\
\hline Average & 73 & 33 & 83.65 & 0.083 & 0.057 & 0.383 & & & & \\
\hline \multicolumn{11}{|l|}{ Bleberan } \\
\hline - Red-big flower & 40 & 25 & 30.77 & 0.352 & 0.500 & -0.420 & & & & \\
\hline - Yellow-big flower & 44 & 32 & 5.56 & 0.325 & 0.313 & 0.038 & & & & \\
\hline - Red-small flower & 56 & 33 & 29.63 & 0.364 & 0.409 & -0.124 & & & & \\
\hline Average & 47 & 30 & 21.99 & 0.347 & 0.407 & -0.169 & & & & \\
\hline \multicolumn{11}{|l|}{ Petir } \\
\hline - Red-big flower & 2340 & 33 & 99.32 & 0.105 & 0.056 & 0.470 & & & & \\
\hline - Yellow-big flower & 936 & 36 & 97.86 & 0.089 & 0.083 & 0.060 & & & & \\
\hline - Red-small flower & 1404 & 40 & 97.86 & 0.106 & 0.075 & 0.292 & & & & \\
\hline \multirow[t]{2}{*}{ Average } & 1560 & 36 & 98.38 & 0.100 & 0.071 & 0.274 & & & & \\
\hline & & & & & & & 0.215 & 0.301 & $8.59 \%$ & $28.56 \%$ \\
\hline \multicolumn{11}{|l|}{ Floral variants } \\
\hline Red-big flower & 2579 & 159 & & 0.254 & 0.219 & 0.138 & & & & \\
\hline Yellow -big flower & 1074 & 123 & & 0.229 & 0.186 & 0.188 & & & & \\
\hline \multirow[t]{2}{*}{ Red-small flower } & 1596 & 146 & & 0.247 & 0.223 & 0.099 & & & & \\
\hline & & & & & & & 0.243 & 0.301 & $5.74 \%$ & $19.09 \%$ \\
\hline
\end{tabular}

Note: $\mathrm{H}_{\mathrm{e}}=$ Hardy-Weinberg expected panmictic heterozygosity, $\mathrm{H}_{\mathrm{o}}=$ observed heterozygosity, $\mathrm{F}_{\text {is }}=$ mean fixation index over all loci, the deviation from expected frequencies under Hardy-Weinberg equilibrium, $\mathrm{H}_{\mathrm{s}}=$ heterozygosity within population, $\mathrm{H}_{\mathrm{T}}=$ total heterozygosity, $\mathrm{D}_{\mathrm{ST}}=$ genetic diversity between population, $\mathrm{GsT}_{\mathrm{sT}}=$ the mean proportion of total genetic diversity at polymorphic loci due to differences between population. Clonality refers to the proportion of vegetative vs. reproductively propagated individuals within populations. *Data obtained from Ratnaningrum et al. (2015)

Observed heterozygosity varied with sites $\left(\mathrm{H}_{\mathrm{o}} 0.057\right.$ to $0.407)$ but was similar among floral variants $\left(\mathrm{H}_{\mathrm{o}} 0.186\right.$ to 0.223 ). A moderate level of diversity was existed among both sites $\left(\mathrm{H}_{\mathrm{S}} 0.215 ; \mathrm{H}_{\mathrm{T}} 0.301 ; \mathrm{D}_{\mathrm{ST}}=8.59 \% ; \mathrm{G}_{\mathrm{ST}}=28.56 \%\right)$ and floral variants $\left(\mathrm{H}_{\mathrm{S}} 0.243 ; \mathrm{H}_{\mathrm{T}} 0.301 ; \mathrm{D}_{\mathrm{ST}}=5.74 \% ; \mathrm{G}_{\mathrm{ST}}=\right.$ $19.09 \%)$. Landrace which has experienced heavy exploitation, whether it has had happened in the past (such as Petir) and still on-going (such as Bejiharjo), were more clonalized, had a low genetic diversity $\left(\mathrm{H}_{\mathrm{o}} \quad 0.057\right.$ in Bejiharjo and 0.071 in Petir) and tended to be more inbred (positive $\mathrm{F}_{\mathrm{IS}}, 0.383$ in Bejiharjo and 0.274 in Petir) (Table $3)$.

\section{The value of Cruden's Outcrossing Index (OCI)}

Out of 360 single flowers (180 flowers per variant) measured, those of RSF have smaller diameter $(2.74 \mathrm{~mm})$ compared to the other variants (more than $4 \mathrm{~mm}$ ). However, since those sizes are still within a range of the same score (flower with diameter of 2 to $6 \mathrm{~mm}$ scored 2), therefore all variants gained score 2 . In each variant, male organ matures before the female, and therefore these three variants were scored 1 . In RSF, pistil and stamen are at similar height with more possibility to inter-mate, and therefore was scored 0 . In RSF, generally pistil is at the higher position in relative to the stamen, and therefore this variant scored 1. Both of bigger flowers, RBF and YBF, produce pistil which has lower or similar position to stamen, and therefore these two variants scored 0 . The total of OCI scores were 4 for RSF and 3 for both YBF and $\mathrm{RBF}$, and therefore these three variants are classified into outcrossing taxa (Figure 1; Table 4).

\section{The ISI (Index of Self Incompatibility) of sandalwood at different landraces and variants}

Hand pollination resulted in a significantly different seed set (Figure 2). In landrace with high genetic base, outcrossing preference and zero ISI value (ISI $=0$; completely self-incompatible), selfing resulted in a very low seed set or even failed. The highest seed set was gained from cross-intraspecific mating between different genotypes within the same variant.

Contrastly, the clonal population which used to undergo a long-term inbreeding, altered its breeding system from outcrossing to be more inbreeding. In this research, it is shown by a very high ISI ( 3 to $\infty$ ), which implied the highly self-compatible breeding system. In clonal population, self-pollination resulted in some seeds, even it failed to develop in the later phases. 

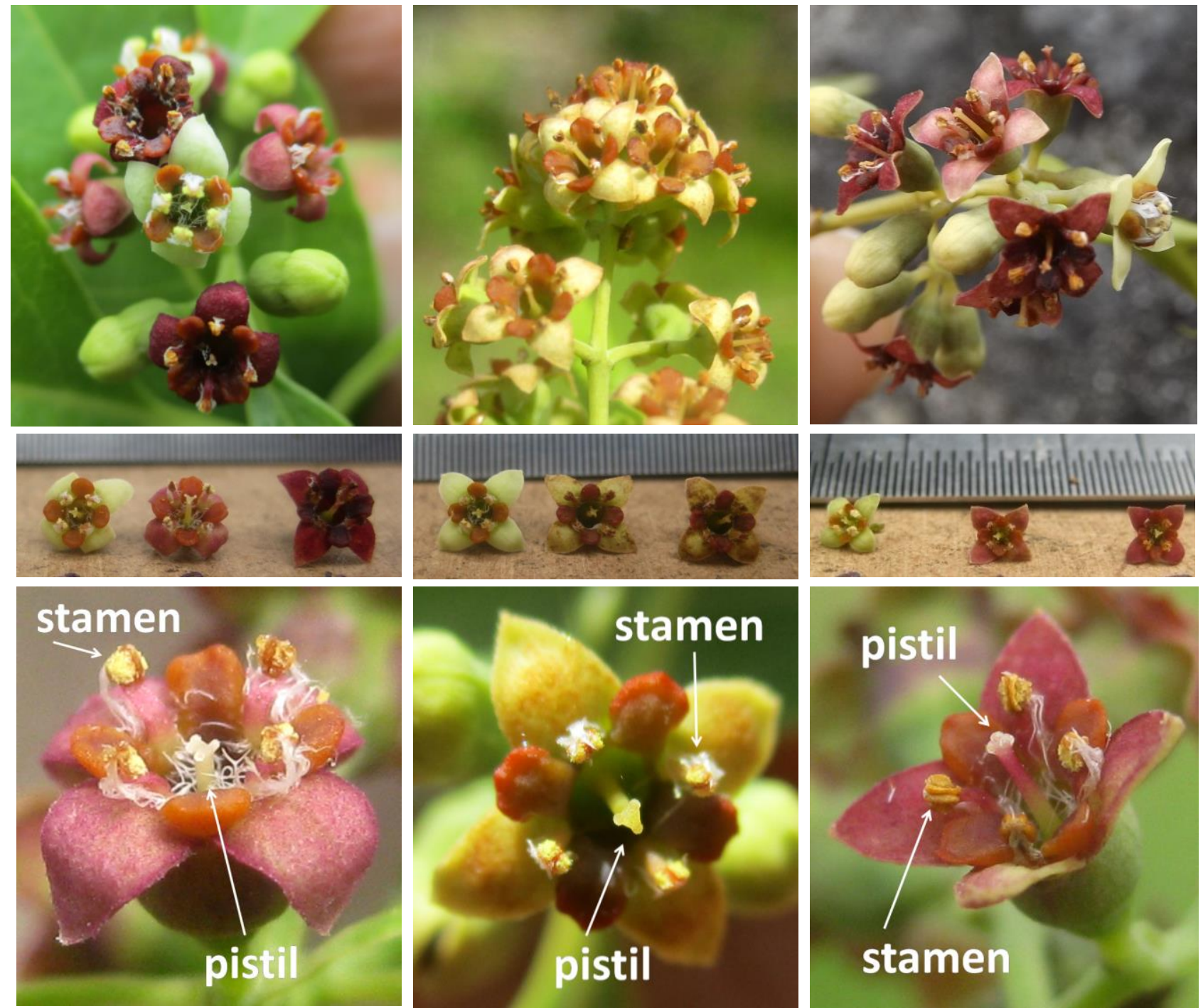

Figure 1. Sandalwood variants in Gunung Sewu, Java, Indonesia: RBF, "red big flower" (left); YBF, “yellow big flower" (middle); and RSF, "red small flower" (right). Both RBF and YSF have similar or lower position of pistil in relation to the stamen, while RSF possessed higher pistil

Table 4. The Cruden's Outcrossing Index scores of three sandalwood variants in Gunung Sewu, Java, Indonesia

\begin{tabular}{|c|c|c|c|c|c|c|}
\hline Characters & $\begin{array}{l}\text { RBF Variant } \\
\text { Measurement results }\end{array}$ & Score & $\begin{array}{r}\text { RSF Variant } \\
\text { Measurement results }\end{array}$ & Score & $\begin{array}{l}\text { YBF Variant } \\
\text { Measurement results }\end{array}$ & Score \\
\hline Floral diameter & $4.68 \mathrm{~mm}$ & 2 & $2.74 \mathrm{~mm}$ & 2 & $4.73 \mathrm{~mm}$ & 2 \\
\hline $\begin{array}{l}\text { Temporal } \\
\text { separation of sexes }\end{array}$ & Protandrous & 1 & Protandrous & 1 & Protandrous & 1 \\
\hline $\begin{array}{l}\text { Spatial separation } \\
\text { of sexes }\end{array}$ & $\begin{array}{l}\text { Hermaphrodite, stylus 2- } \\
3.5 \mathrm{~mm} \text {, in similar or } \\
\text { lower position in relative } \\
\text { to filament }(2-3.5 \mathrm{~mm})\end{array}$ & 0 & $\begin{array}{l}\text { Hermaphrodite, stylus } \\
1.5-2.5 \mathrm{~mm} \text {, in a } \\
\text { similar or higher } \\
\text { position to filament } \\
(1-2 \mathrm{~mm})\end{array}$ & 1 & $\begin{array}{l}\text { Hermaphrodite, stylus } \\
2-3.5 \mathrm{~mm} \text {, in similar or } \\
\text { lower position in } \\
\text { relative to filament (2- } \\
3.5 \mathrm{~mm})\end{array}$ & 0 \\
\hline Total OCI scores & & 3 & & 4 & & 3 \\
\hline
\end{tabular}

\section{Reproductive outputs from the natural pollination of sandalwood at different landraces and variants}

Reproductive ability and seed viability were differed by sites but were similar among variants (Table 5). The lower heterozygosity, highly selfing and self-compatible populations, such as Bejiharjo and Petir, performed lower reproductive ability and viability due to the inbreeding depression. In contrast, the higher genetic base, more outcrossing and self-incompatible populations such as Bleberan performed highest reproductive ability and seed viability. 


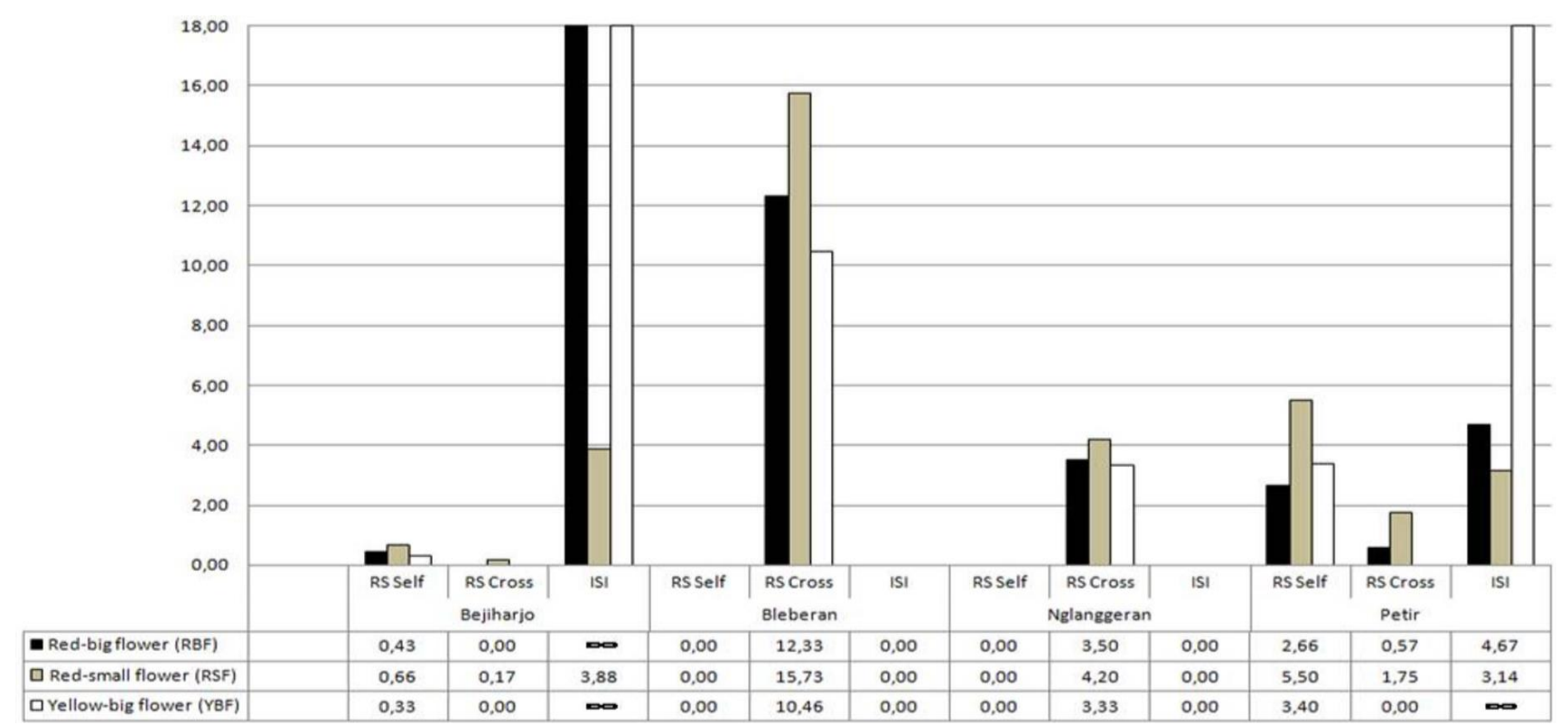

Figure 2. The ISI (Index of Self Incompatibility) value and Reproductive Success (\%) of three sandals floral variants in four landraces in Gunung Sewu, Java, Indonesia

Table 5. The reproductive ability and seed viability from the natural pollination of three sandalwood floral variants in four landraces in Gunung Sewu, Java, Indonesia during April-September 2017 flowering period

\begin{tabular}{|c|c|c|c|c|c|c|c|}
\hline \multirow[b]{2}{*}{$\begin{array}{l}\text { Landraces and } \\
\text { Floral Variants }\end{array}$} & \multirow{2}{*}{$\begin{array}{c}\text { Number of } \\
\text { flowers (from } \\
\text { @ } 3 \text { sampled } \\
\text { trees) }\end{array}$} & \multirow[b]{2}{*}{$\begin{array}{l}\text { Pollinated } \\
\text { Flowers }\end{array}$} & \multirow[b]{2}{*}{$\begin{array}{l}\text { Mature } \\
\text { Fruits }\end{array}$} & \multicolumn{2}{|c|}{ Reproductive Ability } & \multicolumn{2}{|c|}{ Seed Viability } \\
\hline & & & & $\begin{array}{c}\text { Pollination } \\
\text { Effectiveness } \\
(\%)\end{array}$ & $\begin{array}{l}\text { Reproductive } \\
\text { Success (\%) }\end{array}$ & $\begin{array}{c}\text { Germination } \\
\text { test }\end{array}$ & $\begin{array}{c}\text { Tetrazolium } \\
\text { test }\end{array}$ \\
\hline \multicolumn{8}{|l|}{ Landraces } \\
\hline \multicolumn{8}{|l|}{ Nglanggeran } \\
\hline - Red-big flower & 1248 & 112 & 43 & 8.97 & 3.45 & 20.00 & 80 \\
\hline - Yellow-big flower & 2275 & 273 & 77 & 12.00 & 3.38 & 20.33 & 80 \\
\hline - Red-small flower & 1367 & 196 & 52 & 14.34 & 3.80 & 22.84 & 100 \\
\hline Average & & & & 11.77 & 3.54 & 21.06 & 86.67 \\
\hline \multicolumn{8}{|l|}{ Bejiharjo } \\
\hline - Red-big flower & 2110 & 54 & 9 & 2.56 & 0.43 & 0 & 0 \\
\hline - Yellow-big flower & 2290 & 50 & 6 & 2.18 & 0.26 & 0 & 0 \\
\hline - Red-small flower & 1857 & 88 & 37 & 4.74 & 1.99 & 0 & 0 \\
\hline Average & & & & 3.16 & 0.89 & 0.00 & 0.00 \\
\hline \multicolumn{8}{|l|}{ Bleberan } \\
\hline - Red-big flower & 1048 & 297 & 120 & 28.34 & 11.45 & 37.66 & 100 \\
\hline - Yellow-big flower & 1653 & 463 & 176 & 28.01 & 10.65 & 40.00 & 100 \\
\hline - Red-small flower & 1248 & 314 & 128 & 25.16 & 10.26 & 40.77 & 100 \\
\hline Average & & & & 27.17 & 10.79 & 39.48 & 100.00 \\
\hline \multicolumn{8}{|l|}{ Petir } \\
\hline - Red-big flower & 1033 & 281 & 111 & 27.20 & 10.75 & 75.66 & 80 \\
\hline - Yellow-big flower & 1545 & 252 & 105 & 16.31 & 6.80 & 79.80 & 100 \\
\hline - Red-small flower & 1440 & 301 & 132 & 20.90 & 9.17 & 80.00 & 80 \\
\hline Average & & & & 21.47 & 8.91 & 78.49 & 86.67 \\
\hline F stat. & & & & $23.9038 *$ & $63.8928 *$ & $2130.0969^{*}$ & $159.2000 *$ \\
\hline P-value & & & & 7.49E-06* & $3.15 \mathrm{E}-08 *$ & $2.975 \mathrm{E}-17^{*}$ & $1.543 \mathrm{E}-10 *$ \\
\hline \multicolumn{8}{|l|}{ Floral variants } \\
\hline Red-big flower & & & & 16.19 & 5.58 & 35.61 & 60.00 \\
\hline Yellow-big flower & & & & 16.15 & 4.97 & 36.80 & 63.33 \\
\hline Red-small flower & & & & 16.30 & 5.56 & 37.27 & 63.33 \\
\hline F stat. & & & & 0.0005 & 0.0345 & 0.0033 & 0.0093 \\
\hline $\mathrm{P}$-value & & & & 0.9995 & 0.9662 & 0.9967 & 0.9908 \\
\hline
\end{tabular}

Note: $F$ ratios and $P$ values have resulted from variance analysis among variants and landraces. Asterix $(*)$ represents significantly differences in $\mathrm{P}<0.05$ 


\section{Discussions}

Results confirmed the first hypothesis which stated that floral structures differed by variants. Even the observed heterozygosity was similar, there were differences on allele frequency and dominance among variants. The RBF and RSF variants were genotypically similar, which was proven by the similar allele dominancy in isozyme analysis. The YBF was somehow performed different genetic structure. The Dia- 1 loci of YBF were dominated by "c" allele, while those of RSF and RBF were dominated by "b" allele. In $S k d-1$ loci, allele "a" dominated the RBF and RSF variants, while YBF was dominated by "c" allele. Most of genetic diversity was maintained within variant, and some observed diversity has existed among variants ( $\mathrm{D}_{\mathrm{ST}}=$ $\left.5.74 \% ; \mathrm{G}_{\mathrm{ST}}=19.09 \%\right)$.

However, significant genetically differences observed in this study were caused by the differences in genetic base among sites $\left(D_{\mathrm{ST}}=8.59 \% ; \mathrm{G}_{\mathrm{ST}}=28.56 \%\right)$, and not by the floral structure differences among variants. Landrace which experienced heavy exploitation (such as Petir and Bejiharjo) lost many parent trees and most of the remnant parent trees are genotypically identic. Since sandalwood has strong ability to propagate vegetatively, therefore in such landraces, clonality event occurred and mating in the next generations was dominated by geitonogamy. Studies on $S$. album in other regions, such as Southern India (Dani et al. 2011) and peninsular India (Rao et al. 2007) also reported similar results, in which the clonalized and lower genetic bases' populations performed lower heterozygosity, lost more alleles and tended to be more inbreeding. Study on other sandals species also reported similar effects of genetic base and clonality to the population genetic diversity. RFLP-based study on S. spicatum in Western Australia showed that clonalized populations performed significantly lower heterozygosity (Byrne et al. 2003). Microsatellite-based study on S. insulare in insular Pacific reported that significant homozygosity was only observed within clonalized population $\left(\mathrm{H}_{0} \quad 0.28 ; 58 \%\right.$ level of clonalities) and not in those which has higher genetic base $\left(H_{o}\right.$ 0.49), respectively (Lhuillier et al. 2006). RAPD-based analysis on five clonalized populations of S. lanceolatum in south-eastern Victoria, Australia reported very low heterozygosity $\left(\mathrm{H}_{\mathrm{S}}\right.$ 0.06) (Warburton et al. 2000).

This study found no differences in the breeding system among variants. The OCI value scored 3 or more for all of variants, indicated the outcross-mating system. Many studies revealed that $S$. album is a predominantly outbreed (Sindhu-Vereendra and Anantha-Padmanabha 1996; Suma and Balasundaran 2003; Rughkla et al. 2006; Tamla et al. 2012). In fact, the existence of non-differentiated perianth, the small-sized flower, and few pollen and nectars, are the characteristic features of autogamous plants. Therefore, sandal flowers have general tendency to be a more self (Sindhu-Vereendra and Anantha-Padmanabha 1996). However, many experiments showed that sandal flowers performed both spatial- and temporal-separation of sexes in order to prevent selfing. Temporal separation of sexes was exhibited by dichogamous-protandrous mechanism (male organ mature before stigma receptivity) (Sindhu-Vereendra and Anantha-Padmanabha 1996; Suma and Balasundaran 2003; Rughkla et al. 2006; Tamla et al. 2012; Ratnaningrum and Indrioko 2015; Ratnaningrum et al. 2016). In addition, spatial separation of sexes was possessed by heterostylous and heteranthery type of flowers, such a different position of anthers in relative to the stigmatic level. In case of S. album flowers, some trees have flowers with style at or slightly below the level of the top of the anthers, while some other have higher style than the anthers (Sindhu-Vereendra and Anantha-Padmanabha 1996; Syahbudin et al. 2005; Rughkla et al. 2006; Tamla et al. 2012; Arifriana et al. 2017). Previous study in Wanagama, the Middle Zone of Gunung Sewu, revealed two forms of sandalwood: S. album Linn. form depressedfructus, with round-depressed fruit and the higher stigma in relative to stamen; and S. album Linn. form album-globose which have round fruits and a similar height of sexual organs (Syahbudin et al. 2005). Morphological-based study in Petir discovered the variant with yellowish orange color of perigonium, and found differences on the size and arrangements of sexual organs (Arifriana et al. 2017). Genetic control on the sandal floral characters has also reported in six $S$. album variants in Southern India (Rughkla et al. 2006; Rao et al. 2007). S. album in Australia tended to have red to maroon color, while yellow is the specific features of S. spicatum and S. lanceolatum flowers (Tamla et al. 2012).

This results also confirmed the evolution theory which stated that during the long-term evolutionary processes, a species with outcrossing preference will enlarge the floral size and/or performed separation of sexes, both spatially and/or temporally (Herlihy and Eckert 2005; Barrett 2011). An outcrosser Schima superba flower in the Southern China tropical forest sized more than $6 \mathrm{~mm}$, is hermaphrodite protogynous, and scored 4 for OCI (Yang et al. 2017). Flowers of Tetracentron chinense grew in the same region are very small-sized, hermaphrodite without any separation of sexes, having OCI score less than 3 , and were proven to have mixed mating with selfing preference (Gan et al. 2013). Study on several Brassicaceae in Australia showed that species with larger flower and separation of sexes, which could be both spatially or temporally, scored higher OCI and tended to be more outcrossing (Salisbury et al. 2017). Similarly, other studies also revealed that the size of corolla, length of filament and anthers, and the position of sexual organs, all were positively correlated to the quality of pollen transferred; hence the heterostylous and heteranthery flowers tended to be more outcrosser. Other study identified differences on the size and arrangement of sexual organs on 25 biotically pollinated plants of the Chaco Serrano Forest, Argentina, that was resulting in the differences of outcrossing rate (Fernandez et al. 2009).

Results of this study confirmed the second hypothesis since the breeding systems is differed by the population heterozygosity. Commonly, selfing and outcrossing rate supposed to be affected by floral traits such as the number of flowers and flowering trees, floral size and the position of reproductive organs (Herlihy and Eckert 2005; Arroyo et 
al. 2006; Barrett 2011). This study found differences in mating system among sites, however, it did not relate to the differences in floral traits. Even all of variants are outcrosser according to OCI value, the breeding preference in each of sites is more determined by the parental genetic diversity and the degree of clonality.

In this study, landrace with higher clonality and lower genetic base tended to be more inbreeding. Studies on other sandals species also reported similar effects of genetic base and clonality to the mating systems. RFLP-based study on S. spicatum reported a high level of inbreeding in some of clonalized populations in Western Australia (Byrne et al. 2003). Microsatellite-based study on $S$. insulare in insular Pacific found that a high level of inbreeding was only observed within clonalized population ( $\mathrm{F}_{\mathrm{IS}} 0.12 ; 58 \%$ level of clonalities), and not in those with higher genetic diversity ( $F_{I S}-0.07$ ) (Lhuillier et al. 2006). RAPD-based analysis on five clonalized populations of S. lanceolatum in Australia reported a very high inbreeding depression (Warburton et al. 2000). A strong relationship between the parental genetic diversity and outcrossing rate might be related to the mating system of the outbreeding plants (Barrett 2011). The increase of selfing, which reduces heterozygosity, may occur in the outcrossing population which subjected to the low parental genetic base (Byrne et al. 2003; Bottin et al. 2007; Rao et al. 2007) or strongly clonalized (Warburton et al. 2000; Lhuillier et al. 2006; Dani et al. 2011; Indrioko and Ratnaningrum 2015) condition. Furthermore, a high inbreeding in a naturally outbreeding species may promote population bottlenecks, genetic drift and inbreeding depression (Warburton et al. 2000; Dani et al. 2011), such conditions which increase rare and missing alleles (Byrne et al. 2003; Ratnaningrum et al. 2015, 2017a), reduce heterozygosity and reduce reproductive fitness (Warburton et al. 2000; Lhuillier et al. 2006; Indrioko and Ratnaningrum 2015; Ratnaningrum et al. 2015, 2017a).

In order to prevent loss of generation due to inbreeding, plant may also develop the self-incompatibility mechanism, such a genetic mechanism to inhibit the occurrence of offsprings resulted from self-fertilization. This study revealed that in landrace with higher genetic base, outcrossing preference and zero ISI value (ISI $=0$; completely self-incompatible), selfing resulted in a very low seed set or even failed. Contrastly, the clonal population which used to undergo a long-term inbreeding, altered its breeding system from outcrossing to be more inbreeding. In this study, it is shown by a very high ISI (3 to $\infty$ ), which implied the highly self-compatible breeding system. In clonal population, self-pollination resulted in some seeds, even it failed to develop in the later phases. Other studies reported high pollen fertility $(88.4 \%)$ in $S$. album in India (Suma and Balasundaran 2003) and high rate of pollination effectiveness (10 to 40\%) in S. album in Java island (Ratnaningrum et al. 2016, 2018), but the lower percentage of mature seeds indicated the occurrence of genotypic barriers to embryo development due to the selfincompatibility mechanism (Sindhu-Vereendra and Anantha-Padmanabha 1996; Warburton et al. 2000; Suma and Balasundaran 2003; Rughkla et al. 2006). Self- incompatibility, which may occur at both pre- and postzygotic levels, have arisen in evolution as a way to promote population diversity by preventing self-fertilization in sandalwood (Sindhu-Vereendra and Anantha-Padmanabha 1996; Tamla et al. 2012; Ratnaningrum et al. 2016, 2018). Similar result was also reported with the self-incompatible Genista anglica in which the number of seeds decreased with decreasing population size (Tsaliki and Diekmann 2011), and the authors considered the constraints due to self-incompatibility in isolated populations to be the most responsible factor. Limited or failed sexual reproduction in the clonalized populations of sandalwood may also be resulted from pollen-pistil incompatibility or pistil dysfunction (Warburton et al. 2000; Indrioko and Ratnaningrum 2015).

This study confirmed the third hypothesis, since the reproductive ability differed by sites due to the difference between heterozygosity and breeding system. In general, the lower heterozygosity, highly selfing and selfcompatible populations performed the lower reproductive ability. Results of this study also confirmed the "reproductive assurance" theory which assumed that during the evolutionary history, species might alter its breeding preference from outcrossing to be more selfing, when the condition which supports cross-breeding was no longer existed (Herlihy and Eckert 2005; Barrett 2011; Gan et al. 2013); such a condition which related to clonality, low genetic base, isolation and fragmentation (Herlihy and Eckert 2005; Arroyo et al. 2006; Ratnaningrum et al. 2017a). Since sandalwood is naturally an outbreeder, it is assumed that it will have less ability to cope with inbreeding depression. However, as a result of selection, the clonalized and/or lower genetic bases' populations will be more inbreeder, and in order to assure its regeneration, will lack the negative effects of inbreeding depression. The two clonalized landraces, Petir and Bejiharjo, confirmed this "reproductive assurance theory". Both sites were the only landraces which able to produce more selfed-seeds, particularly at Petir. This condition was considered as an evidence that self-fertilization has developed to provide reproductive assurance in inbreeding populations (Herlihy and Eckert 2005; Arroyo et al. 2006). However, a very low number of selfed-seeds produced in Bejiharjo were considered as the effect of the early-acting inbreeding depression. Bejiharjo landrace tended to be outcrosser in the past (showed by the negative fixation index of older trees), but switched its breeding system into selfing after lost many parent trees due to fragmentation and heavy harvesting (Indrioko and Ratnaningrum 2015; Ratnaningrum et al. 2017). In the other hand, the evidence of late-acting inbreeding depression was observed in Petir which has been exposed to a clonality condition, and therefore has been dominated by self-mating system, for a relatively longer time period. In Petir, the effect of inbreeding depression will not be expressed until the reproductive outputs reached the seedling level. The success of reproductive at populations which have been subjected to inbreeding for a long time period could be seen as a result of pre-adapted breeding systems, as reported for $C$. euphrasioides in the highland of Andes, 
Chile (Arroyo et al. 2006), Santalum spicatum in Western Australia (Byrne et al. 2003) and S. australocaledonium in New Caledonia (Bottin et al. 2007). Schima superba in the Southern China tropical forest region, which has low ISI (strongly self-incompatible) and strong outcrossing preference, were failed to produce seed from selfpollination (Yang et al. 2017). In contrast, Tetracentron chinense grew in the same region has very high ISI (completely self-compatible), performed mixed mating and preferred selfing (Gan et al. 2013). Study on several Brassicaceae in Australia also showed relationship between high OCI, outcrossing preference and low ISI (highly selfincompatible) (Salisbury et al. 2017).

In conclusion, results partly confirmed the first hypothesis which stated that floral structures differed by variants, but the observed heterozygosity is similar $\left(\mathrm{H}_{\mathrm{o}}\right.$ 0.186 to 0.223 ). However, allele frequency and dominancy differed among variants. Some of genetic diversity is existed among variants ( $\mathrm{D}_{\mathrm{ST}}=5.74 \% ; \mathrm{G}_{\mathrm{ST}}=19.09 \%$ ). However, significant genetical differences were more caused by the differences on genetic base among sites $\left(\mathrm{H}_{\mathrm{o}}\right.$ 0.057 to $0.407 ; \mathrm{H}_{\mathrm{S}} 0.243 ; \mathrm{H}_{\mathrm{T}} 0.301 ; \mathrm{D}_{\mathrm{ST}}=8.59 \% ; \mathrm{G}_{\mathrm{ST}}=$ $28.56 \%$ ), and not by the floral structure differences among variants. The more clonalized landraces had a low genetic diversity. Results partly confirmed the second hypothesis since the breeding systems is differed by the population heterozygosity, even it is similar among variants. All of variants are outcrosser according to OCI value (> 3), however, breeding system differed by sites due to different genetic base and clonality among sites. Landrace with higher clonality and lower genetic base has lower heterozygosity, lost more alleles and tended to be more inbreeding. The self-incompatibility level was also differed by sites. Landrace with high genetic base, outcrossing preference and zero ISI value (ISI $=0$; completely selfincompatible) failed to produce seeds from selfing. In contrast, clonal populations altered its breeding system to be more inbreeding, and were highly self-compatible (ISI 3 to $\infty)$. Results partly confirmed the third hypothesis, since the reproductive ability is differed by sites due to the difference on heterozygosity and breeding system, even it is similar among variants. In general, the lower heterozygosity, highly selfing and self-compatible populations performed lower reproductive ability. Results also confirmed the "reproductive assurance" theory which assumed that species might alter its breeding preference from outcrossing to be more selfing, when the condition which supports cross-breeding was no longer existed.

\section{REFERENCES}

Arifriana R, Indrioko S, Syahbudin A. 2017. The variation on sandalwood (Santalum album Linn.) based on foliar and floral morphology in Petir, Rongkop, Gunungkidul. Jurnal Ilmiah Kehutanan 11: 97-108. [Indonesian].

Arroyo MTK, Muñoz MS, Henríquez C, Till-Bottraud I, Pérez F. 2006. Erratic pollination, high selfing levels and their correlates and consequences in an altitudinally widespread above-tree-line species in the high Andes of Chile. Acta Oecologica 30: 248-257.

Bano HH. 2001. Role of sandalwood to the economic sector of NTT: now and then. Berita Biologi 5 (5): 469-475. [Indonesian].
Barrett SCH. 2011. Why reproductive systems matter for the invasion biology of plants. In: Richardson DM (ed.). Fifty Years of Invasion Ecology. Blackwell Publishing Ltd., New Jersey.

Bottin L, Tassin J, Nasi R, Bouvet J. 2007. Molecular, quantitative and abiotic variables for the delineation of evolutionary significant units: case of sandalwood (Santalum austrocaledonicum Vieillard) in New Caledonia. Conserv Genet 8: 99-109.

Byrne M, MacDonald B, Broadhurst L, Brand J. 2003. Regional genetic differentiation in Western Australian sandalwood (Santalum spicatum) as revealed by nuclear RFLP analysis. Theor Appl Genet 107: $1208-1214$.

Copeland LO, McDonald MB. 2001. Principles of seed science and technology. 4th edition. Kluwer Academic Publishers. Norwell, Massachusetts.

da Silva JAT, Page T, Zhang X, Kher MM, Nataraj M, Soner D, Ma G. 2016. Sandalwood: basic biology, tissue culture, and genetic transformation. Planta 243: 847-887.

Dani KGS, Ravikumar P, Kumar RP, Kush A. 2011. Genetic variation within and among small isolated populations of Santalum album. Biol Plantarum 55 (2): 323-326.

Fathin AN, Ratnaningrum YWN. 2018. The differences in floral structure of three sandalwood variants in one of Gunung Sewu (Indonesia) population, and their consequences on visitor diversity and visitation rate. Biodiversitas 19(3): 1097-1101.

Fernandez VA, Galetto L, Astegiano J. 2009. Influence of flower functionality and pollination system on the pollen size-pistil length relationship. Org Div Evol 9: 75-82. 2009.

Gan X, Cao L, Zhang X, Li H. 2013. Floral biology, breeding system and pollination ecology of an endangered tree Tetracentron sinense Oliv. (Trochodendraceae). Botanical Studies 2013 (54): 50.

Harbaugh DT, Baldwin BG. 2007. Phylogeny and biogeography of the Sandalwoods (Santalum, Santalaceae): repeated dispersals throughout Pacific. Am J Bot 94(6): 1028-1040.

Herlihy CR, Eckert CG. 2005. Evolution of self-fertilization at geographical range margins? A comparison of demographic, floral, and mating system variables in central vs. peripheral populations of Aquilegia canadensis (Ranunculaceae). Am J Bot 92(4): 744-751.

Indrioko S, Ratnaningrum YWN. 2015. Habitat loss caused clonality, genetic diversity reduction and reproductive failure in Santalum album, an endangered endemic species of Indonesia. Proc Environ Sci 5: 613-620.

IUCN. 1994. IUCN Red List Categories and Criteria: Version 2.3. IUCN Species Survival Commission. International Union for Conservation of Nature and Natural Resources. Glad, Switzerland, and Cambridge. UK.

IUCN. 2009. IUCN Red List Categories and Criteria: Version 3.1. IUCN Species Survival Commission. International Union for Conservation of Nature and Natural Resources. Glad, Switzerland, and Cambridge, UK

Kementerian Kehutanan RI (Ministry of Forestry, Indonesia). 2012. The replanting of one million sandalwoods in Nusa Tenggara Timur. Ministry of Forestry, Republic of Indonesia. Jakarta, Indonesia. [Indonesian]

Lhuillier E, Butaud JF, Bouvet JM. 2006. Extensive clonality and strong differentiation in the Insular Pacific tree Santalum insulare: implications for its conservation. Ann Bot 98: 1061-1072.

Mooy LM, Kasim M, Kantur D. 2013. The morphological characteristics of sandalwood seedling planted on the water-stressed soils of alfisols and vertisols. Buletin Pertanian Terapan 20 (2): -. [Indonesian].

Owens JN, Sornsathapornkul P, Thangmitcharoen S. 2001. Studying Flowering and Seed Ontogeny in Tropical Forest Trees. ASEANCanada Forest Tree Seed Centre. Muak-lek, Saraburi.

Rao MN, Ganeshaiah KN, Shaanker RU. 2007. Assessing threats and mapping sandal resources to identify genetic 'hot-spot' for in-situ conservation in peninsular India. Conserv Genet 8: 925-935.

Ratnaningrum YWN, Indrioko S, Faridah E, Syahbudin A. 2015. The effects of population size on genetic parameters and mating system of sandalwood in Gunung Sewu, Indonesia. Indo J Biotech 20(2): 182201.

Ratnaningrum YWN, Indrioko S, Faridah E, Syahbudin A. 2016. Flowering and seed production of sandalwood (Santalum album Linn., Santalaceae) along environmental gradients in Gunung Sewu Geopark, Indonesia. Nusantara Biosci 8 (2): 180-191.

Ratnaningrum YWN, Indrioko S, Faridah E, Syahbudin A. 2017a. Gene flow and selection evidence of sandalwood under various population 
structures in Gunung Sewu (Java, Indonesia), and its effect on genetic differentiation. Biodiversitas 18 (4): 1493-1505.

Ratnaningrum YWN, Indrioko S, Faridah E, Syahbudin A. 2017b. Variation on flowering characters among sandalwood variants and landraces along geographical gradients in Gunung Sewu. Jurnal Ilmu Kehutanan 2: 173-195. [Indonesian]

Ratnaningrum YWN, Indrioko S, Faridah E, Syahbudin A. 2018. Population structures and seasons affected flowering, pollination and reproductive outputs of sandalwood Gunung Sewu, Java, Indonesia Nusantara Biosci 10(1): 12-26.

Ratnaningrum YWN, Indrioko S. 2015. Response of flowering and seed production of sandalwood (Santalum album linn., Santalaceae) to climate changes. Proc Environ Sci 5: 665-675.

Rughkla A, McComb JA, Jones MGK. 2006. Intra-and inter specific pollination of Santalum spicatum and S. album. Aus J Bot 45(6): 1083-1095.

Salisbury PA, Fripp YJ, Gurung AM, Williams WM. 2017. Is floral structure a reliable indicator of breeding system in the Brassicaceae? PLoS One 12(3): e0174176 https://doi.org/10.1371/journal.pone.0174176

Seido K. 1993. Manual of isozyme analysis. Japan International Cooperation Agency (JICA). Yokohama.

Sindhu-Veerendra HCS, Anantha-Padmanabha HSA. 1996. The breeding system in Sandal (Santalum album L.). Silv Gen 45 (4): 188-190.
Suma TB, Balasundaran M. 2003. Isozyme variation in five provenances of Santalum album in India. Aus J Bot 51(3): 243 - 249.

Syahbudin A, Adriyanti DT, Nalvien. 2005. Morphological variation of sandalwood planted in provenance trial in Wanagama, Gunungkidul. [Final Report on DPP Research Grant]. Faculty of Forestry. Universitas Gadjah Mada. Yogyakarta. [Indonesian]

Tamla HT, Cornelius JP, Page T. 2012. Reproductive biology of three commercially valuable Santalum species: development of flowers and inflorescences, breeding systems, and interspecific crossability. Euphytica 184: 323-333.

Tsaliki M, Diekmann M. 2011. Population size, pollination and reproductive success in two endangered Genista species. Flora 206: 246-250.

UNEP. 2007. UNEP-WCMC Species Databases: Santalum album L. United Nations Environment Program - World Conservation Monitoring Center. Cambridge, UK.

Warburton CL, James EA, Fripp YJ, Trueman SJ, Wallace HM. 2000. Clonality and sexual reproductive failure in remnant populations of Santalum lanceolatum (Santalaceae). Biol Conserv 96 (1): 45-54.

Yang H, Zhang R, Song P, Zhou Z. 2017. The floral biology, breeding system and pollination efficiency of Schima superba Gardn. et Champ. (Theaceae) Forests 2017 (8): 404. DOI: 10.3390/f8100404 